\title{
An Analysis of Continuous Sandwich Panels with Profiled Faces
}

\author{
Metod Čuk ${ }^{1}$ - Franc Kosel ${ }^{1}$ - Nenad Zrnić ${ }^{2}$ - Boris Jerman ${ }^{1}$, \\ 1 University of Ljubljana, Faculty of Mechanical Engineering, Slovenia \\ 2 University of Belgrade, Faculty of Mechanical Engineering, Serbia
}

\begin{abstract}
Structural sandwich panels made of two thin steel facings that are bonded to a thick mineral wool core are often used as roofing material. This paper explores an application of numerical simulations in the investigation of structural behaviour of long span, continuous roof sandwich panels with profiled faces. Because of the required higher load-bearing capacity and strict deflection limitations, roof sandwich panels usually have one of the cover faces strongly profiled. A finite element analysis and an experimental study of a long span sandwich panel (with an inner strongly profiled and a flat outer face) in two-span configuration with transverse loading were conducted with a special attention given to the failure modes and bearing capacity prediction. The results obtained from the experiment confirmed the finite element analysis results.

Keywords: testing, finite element method, structural analysis, sandwich structures, strongly profiled faces, mineral wool, failure mode

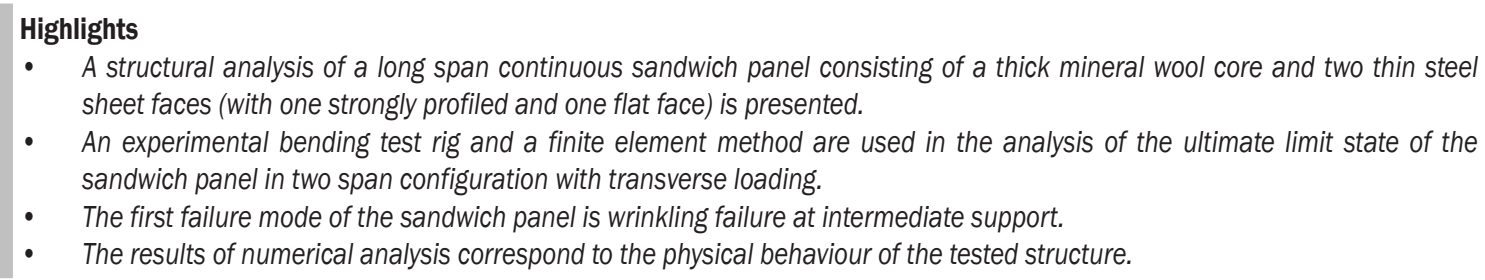

\section{INTRODUCTION}

Structural sandwich panels are composites consisting of two relatively thin facings enclosing a relatively thick core. The properties required for the faces are high stiffness (giving high flexural rigidity), high tensile and compressive strength, impact and wear resistance, environmental resistance (UV, heat, etc.), and surface finish. The properties of primary interest for the core are low density, shear modulus, shear strength, stiffness perpendicular to the faces, and (thermal and sound) insulation [1] and [2].

Sandwich panels used for claddings in the construction of industrial, commercial, and residential buildings that are usually mineral wool or polyurethane foam cored with steel sheet faces must as structural elements not only provide a function of the building enclosure, but also an important load-bearing function. While the wall sandwich panels mainly support variable loads such as the wind pressure, the sandwich panels used for roof claddings must also support some permanent loads: mainly their own weight and also the weight of possible solar panels or photovoltaic cells etc., and some variable loads like snow and wind loads, thermal loads, etc. These higher load-bearing requirements and strict deflection limitations are the reason why roof sandwich panels usually have one of the cover faces strongly profiled.

For the structural behaviour of sandwich panels, it is necessary to consider all of the potential failure modes: tensile failure of the faces (due to tensile stress), local buckling (wrinkling) of the faces (due to compressive stress), and shear failure of the core or the adhesion between the core and face. In sandwich panels with thin strongly profiled faces, two additional failure modes are introduced: shear strength of the webs in a profiled face and the support reaction capacity of a profiled face [1]. The first failure mode of long and medium span length continuous multi-span panels is usually the buckling failure at intermediate support due to the interaction between the bending moment and support reaction [3] and [4].

The European standard EN 14509 [5], or European Recommendations published by the European Convention for Constructional Steelwork (ECCS) and the International Building Council (CIB) do not provide detailed design methods for sandwiches with strongly profiled faces. Determination of the load bearing capacity required for the design of sandwich panels is to a large degree based on test results [6].

Hassinen [7], and later Misiek and Hassinen [6] concluded that a calculation procedure based on the design principles developed for trapezoidal sheeting (Eurocode 3 [8] and [9]) was possible by taking into an account the effect of the elastic foundation provided by the core layer. The basic principles of the design model backed by finite element calculations and test results were introduced for sandwich panels with an outer strongly profiled face and a flat inner face. A similar approach was also used by Pokharel and 
Mahendran [10] and [11] for flat and lightly profiled sandwich panels. The investigation of structural behaviour and failure analysis of composite structures through the use of finite element analyses were also shown in [12] and [13].

The objective of this paper is to present a study of the structural behaviour of a continuous roof sandwich panel with flat outer and strongly profiled inner steel faces and a mineral wool core (as shown in Fig. 1) with transverse loading in a two span configuration (studied testing setup is shown in Fig. 3). The studied example was specified by the provider of building envelope solutions (including manufacturing of sandwich panels).

As previously mentioned, the first failure mode of such a long span panel is the buckling failure at intermediate support due to the interaction between the bending moment and positive support reaction. An analytical approach using "Engineer's Theory of Bending" in this case is quite futile. For statically indeterminate panels (panels continuous over two or more spans), to determine the deflections and stresses in panels with profiled faces (when one or both faces of the panel are profiled), a more general analysis is required which takes into account the bending stiffness of the faces [1], as well as the support pressure distribution between the support and the sandwich panel [3] and [4]. In reality, it is relatively difficult to evaluate this interaction. The chances of being able to assess such a multiplicity of factors with sufficient accuracy by theoretical analysis would appear to be very small. The need for tests to analyse the failure criteria is indisputable [1].

To overcome the need for tests, an analysis of the ultimate limit state of the presented sandwich panel was conducted by numerical simulation. The results of the simulation and a comparison to the experimental results are presented.

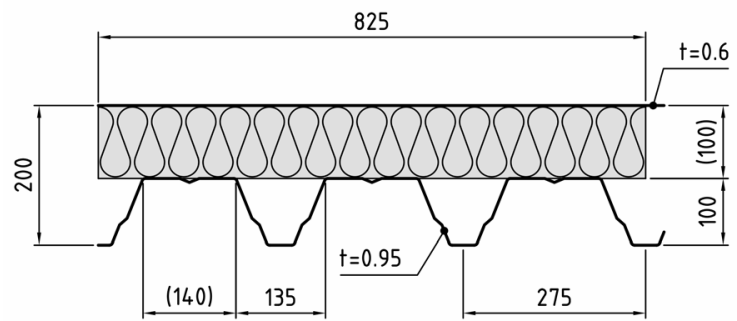

Fig. 1. Transverse (cross sectional) view of roof sandwich panel with a mineral wool core and a strongly profiled inner and a flat outer steel face

\section{FINITE ELEMENT ANALYSIS}

The structural behaviour of sandwich panels in a two span configuration with the inner of the two steel faces strongly profiled was investigated using the ANSYS ${ }^{\circledR}$ simulation software package.

Based on a series of preliminary finite element analyses simulating the experimental setup (see Chapter 2 and Fig. 3), a one-twelfth symmetry finite element model was built, as shown in Fig. 2.

A three-dimensional finite element model of the analysed sandwich panel consists of two different types of finite elements: solid (brick) elements (SOLID185) with large deflection and large strain capabilities were used for the core, and shell elements (SHELL181) that are well suited for large strain nonlinear applications were used to model the outer flat and the inner strongly profiled face. The element formulation is based on logarithmic strain and true stress measures [14]. The combination of brick and shell elements can be used if adequate compatibility conditions are implemented at element interfaces [12] and [15] to [17]. Adhesive layers between the mineral wool core and both steel faces were modelled by using couplings so that the displacement degrees of freedom in all three directions (UX, UY, and UZ) of coincident interface nodes of the elements of the faces and the core were coupled which is common approach in the modelling of bonded layers of different materials (non-metallic or metallic) [18] and [19].

An orthotropic elastic material model was employed to solid elements of the mineral wool core, and a bilinear isotropic hardening material model was applied to steel face shell elements. Mechanical properties and densities of steel faces and mineral wool core based on data provided by the sandwich panel manufacturer are shown in Tables 1 and 2, respectively.

Table 1. Material properties of steel faces

\begin{tabular}{ccccc}
\hline Density & $\begin{array}{c}\text { Elastic } \\
\text { modulus } \\
{[\mathrm{GPa}]}\end{array}$ & $\begin{array}{c}\text { Yield } \\
\text { strength } \\
{\left[\mathrm{Mg} / \mathrm{m}^{3}\right]}\end{array}$ & $\begin{array}{c}\text { Poisson } \\
\text { ratio } \\
{[-]}\end{array}$ & $\begin{array}{c}\text { Tangent } \\
\text { modulus } \\
{[\mathrm{MPa}]}\end{array}$ \\
\hline 7850 & 210 & 355 & 0.3 & 100 \\
\hline
\end{tabular}

Table 2. Material properties of mineral wool core

\begin{tabular}{ccccccccccc}
\hline $\begin{array}{c}\text { Density } \\
{\left[\mathrm{kg} / \mathrm{m}^{3}\right]}\end{array}$ & \multicolumn{3}{c}{$\begin{array}{c}\text { Elastic modulus } \\
{[\mathrm{MPa}]}\end{array}$} & \multicolumn{3}{c}{$\begin{array}{c}\text { Poisson ratio } \\
{[-]}\end{array}$} & \multicolumn{4}{c}{$\begin{array}{c}\text { Shear modulus } \\
{[\mathrm{MPa}]}\end{array}$} \\
\hline$\rho$ & $E_{x}$ & $E_{y}$ & $E_{z}$ & $n_{x y}$ & $n_{y z}$ & $n_{x z}$ & $G_{x y}$ & $G_{y z}$ & $G_{x z}$ \\
\hline 100 & 0.50 & 7.0 & 3.0 & 0 & 0 & 0 & 0.40 & 2.0 & 0.40 \\
\hline
\end{tabular}




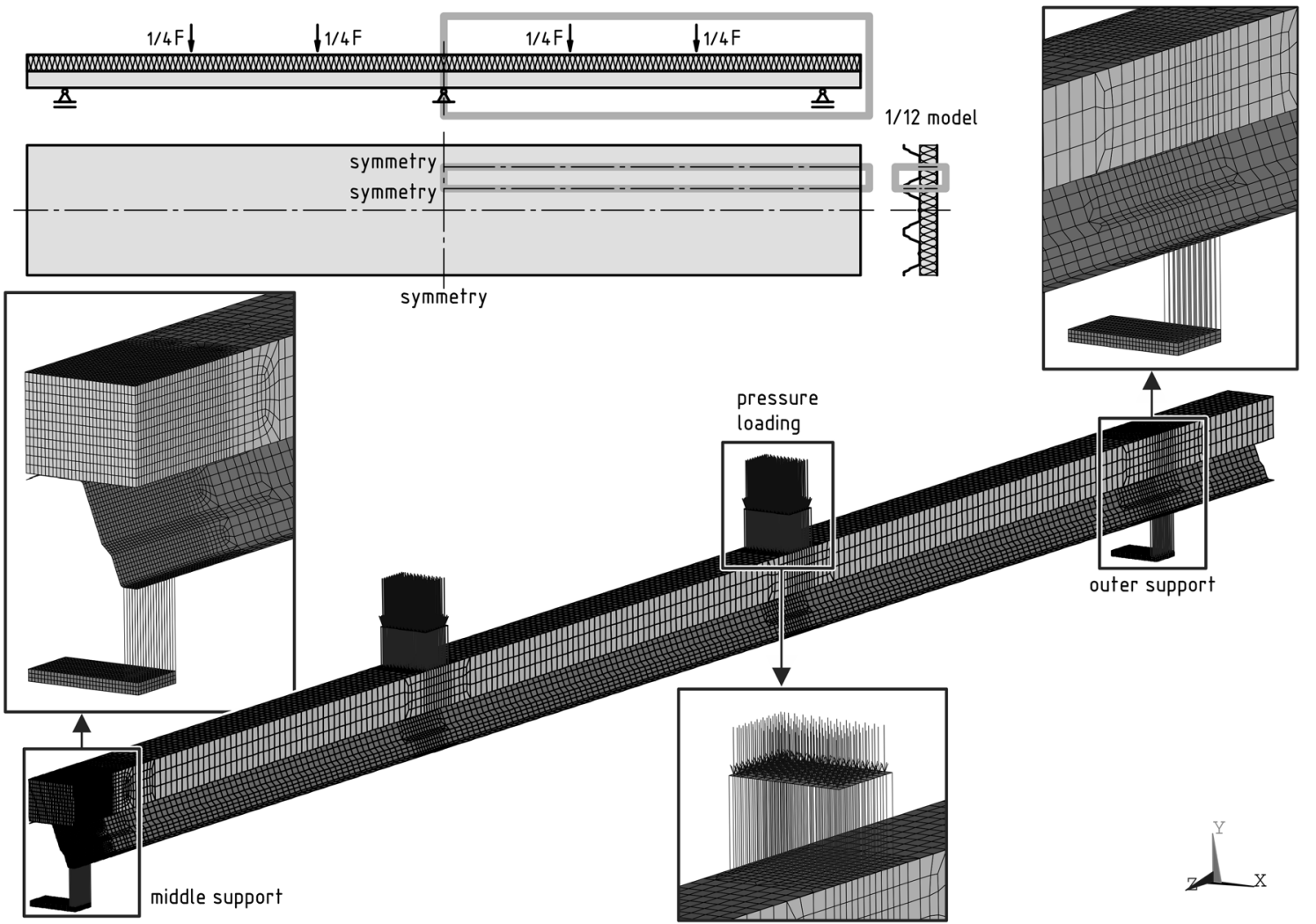

Fig. 2. The one-twelfth symmetry finite element model of sandwich panel in double span configuration with applied loads (symmetry and other boundary conditions not shown)

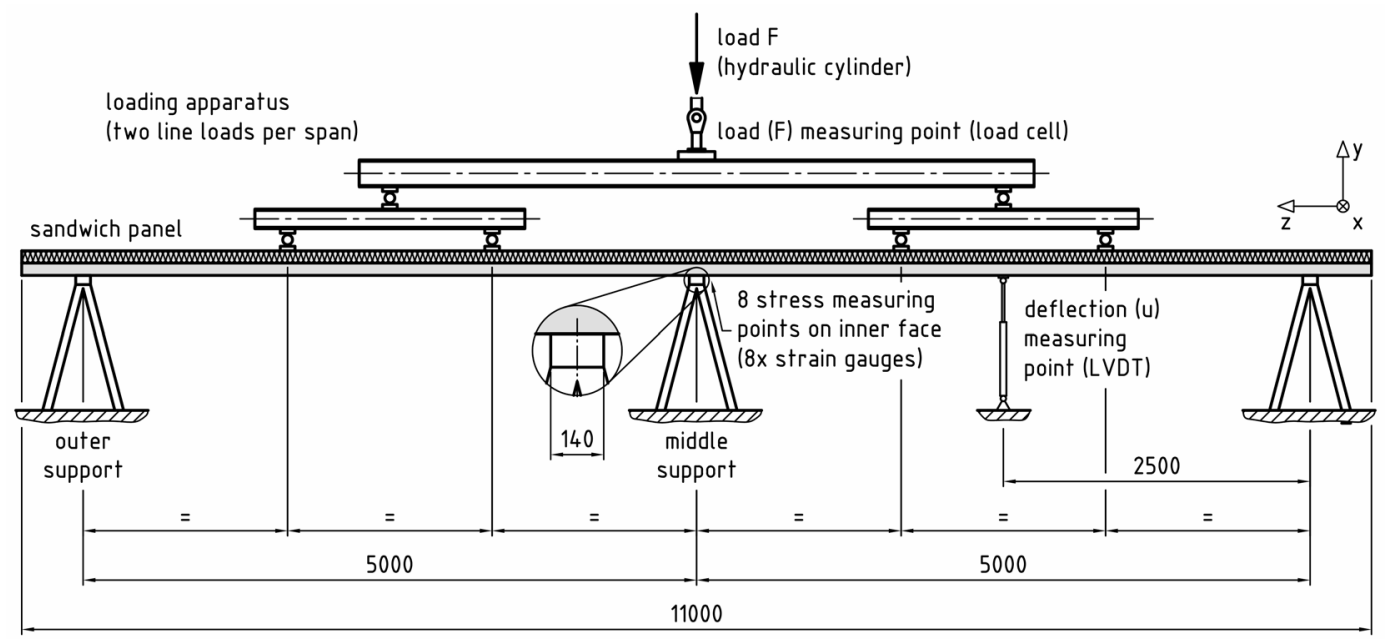

Fig. 3. Experimental setup: sandwich panel in double span configuration with load apparatus

It has to be noted that the coordinate directions used in Table 2 are consistent with the coordinates used in both the finite element and the experimental analyses (see Figs. 2 and 3): the $\mathrm{X}$ axis defines a direction parallel to the width of the panel, the $\mathrm{Y}$ axis defines a direction parallel to the panel thickness, and the $\mathrm{Z}$ axis defines a direction parallel to the length of the sandwich panel.

In addition to the structural solid and shell elements, 3-D spar compression-only elements were used to emulate the simple supports of the bottom flange of the strongly profiled face of the sandwich 


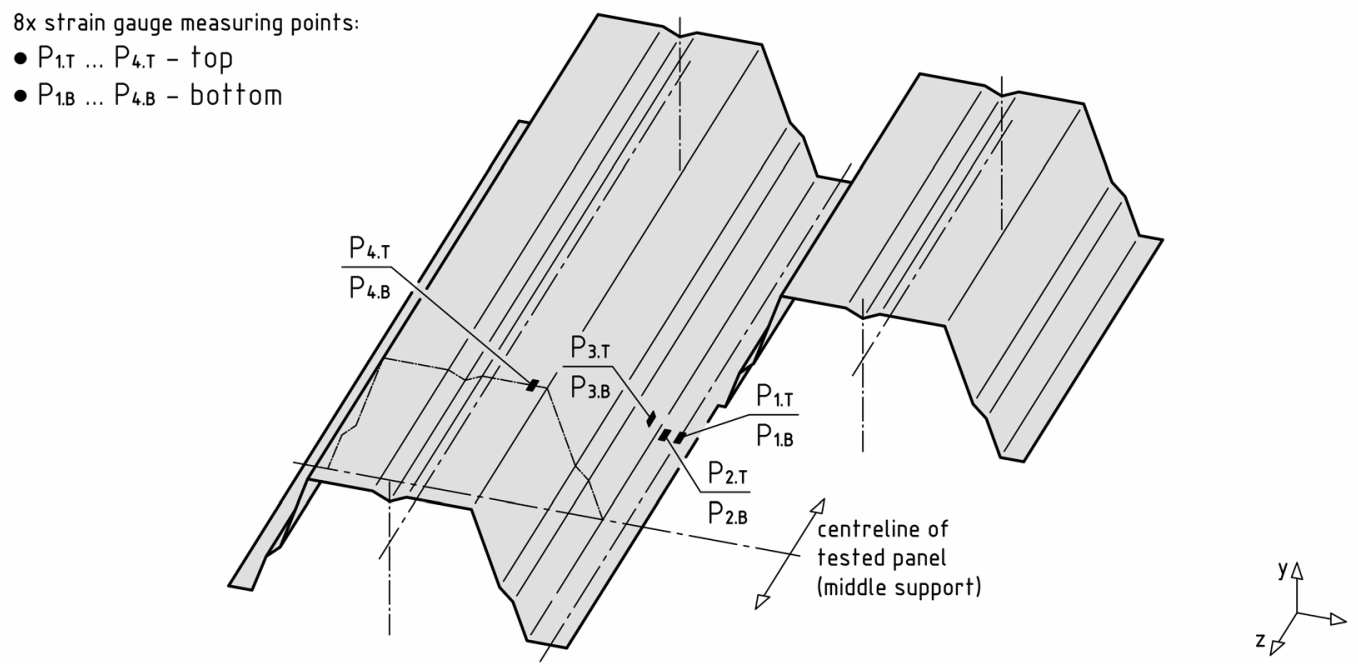

Fig. 4. Position of strain gauge measuring points on strongly profiled inner face of the tested sandwich panel above the middle support - two strain gauges are attached at each of four locations: one at the top surface $\left(P_{1 . T} \ldots P_{4 . T}\right)$ and one at the bottom surface $\left(P_{1 . B} \ldots P_{4 . B}\right)$

panel. 3-D spar elements were also used to apply pressure loading at two loading areas on the flat face, and thus emulate a load apparatus from the experimental setup. A dead load of the load apparatus (a mass of $550 \mathrm{~kg}$ ) was applied to the model by additional constant pressure load, while a dead load of the sandwich panel was applied by specified gravitational acceleration of $9.81 \mathrm{~m} / \mathrm{s}^{2}$ in the $\mathrm{Y}$ direction.

Due to the double symmetry of the tested sandwich panel across two perpendicular planes (parallel to XY and YZ planes) use of one-quarter symmetry model (with width of $412.5 \mathrm{~mm}$, see Fig. 1) would be absolutely correct model. Based on the results from the preliminary analyses that had shown no significant difference in results between "one-quarter" model and the "one-twelfth" model (a sandwich panel model with infinite width i.e. dimension parallel to the $X$ axis, see Fig. 2) the letter model was selected to shorten simulation times. Symmetric boundary conditions were applied at all three vertical "symmetry" planes (marked and labelled "symmetry" on Fig. 2, top left).

The model was solved numerically including large deformation effects.

\section{EXPERIMENTAL INVESTIGATIONS}

In order to verify the results of numerical analysis, an experimental investigation was conducted at the laboratory of the sandwich panel manufacturer. An experimental setup based on a modified bending test rig used for a single span panel bending test (A.5 in [5]) with added middle support was used as shown in Fig. 3. An 11-m long single sandwich panel (transverse cross-sectional view is shown in Fig. 1) is placed horizontally on three equally spaced (by a distance of $5 \mathrm{~m}$ ) simple supports in effectively a two span configuration since the overhangs on both sides were not additionally loaded (dead load only). Transverse loading of the tested panel was accomplished by a hydraulic cylinder. The load from the hydraulic cylinder was applied to the tested panel through a loading apparatus (two equidistant line loads per span).

The total applied transverse load $F$ was measured using a load cell linked between the hydraulic cylinder and the loading apparatus while the midspan deflection $u$ of the inner face was recorded using a linear variable differential transformer (LVDT) (see Fig. 3).

For the measurement of axial bending stresses $\sigma_{\mathrm{z}}$ at eight different measuring points $\left(\mathrm{P}_{1 . \mathrm{T}} \ldots \mathrm{P}_{4 . \mathrm{T}}\right.$ and $\mathrm{P}_{1 . \mathrm{B}} \ldots \mathrm{P}_{4 . \mathrm{B}}$, see Fig. 4) strain gauges (in a quarter Wheatstone bridge configuration) were used. Two strain gauges were attached at each of the four different locations at both the top and the bottom surface of the inner (strongly profiled) steel face in the region above the middle support as shown.

The relevant positions of the stress measuring points on the profiled face of the tested sandwich panel were determined by preliminary finite element analyses. Pairs of measuring points $\mathrm{P}_{1 . \mathrm{T}}$ and $\mathrm{P}_{1 . \mathrm{B}}$, and $\mathrm{P}_{2 . \mathrm{T}}$ and $\mathrm{P}_{2 . \mathrm{B}}$ were located on the bottom, flange while the pair of points $P_{3 . T}$ and $P_{3 . B}$ was placed on 
the web near the bottom flange, and the position of the measuring point pair $\mathrm{P}_{4 . \mathrm{T}}$ and $\mathrm{P}_{4 . \mathrm{B}}$ was selected on the top flange.

\section{RESULTS}

The results of both numerical and experimental analysis of the investigated long span length sandwich panel show an expected ultimate failure mode in the form of the wrinkling failure of a profiled face at the middle support due to the interaction between the bending moment and support reaction, as shown in Fig. 5.

a)

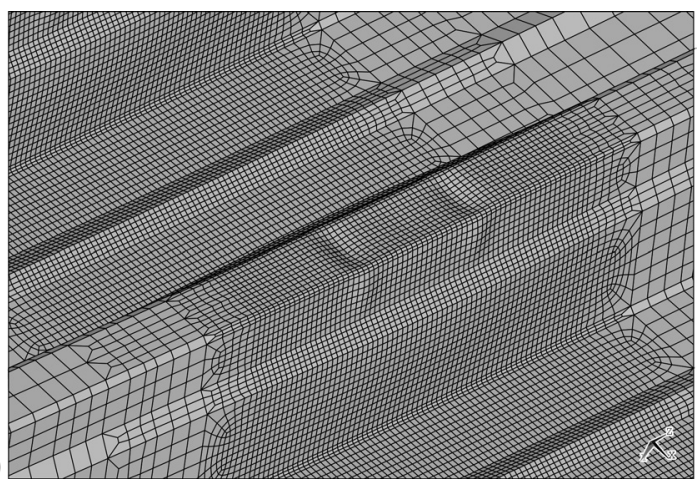

b)

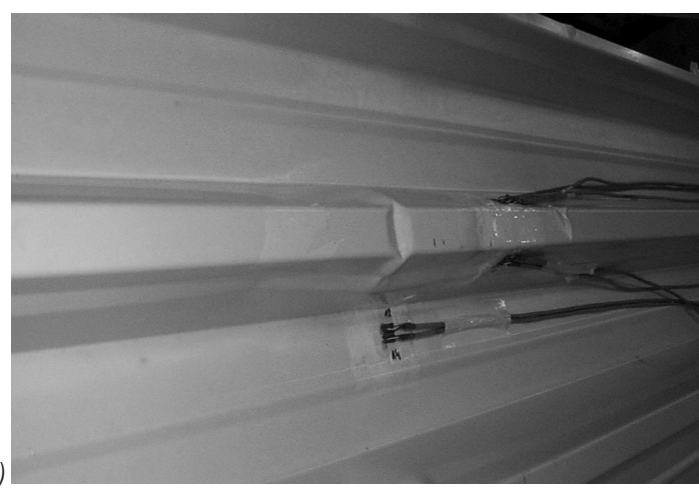

Fig. 5. Failure mode of analysed sandwich panel: support reaction capacity of a profiled face at medium support; (view from below) a) finite element calculation; b) tested specimen

In Fig. 6, calculated results of normal stress distribution $\sigma_{y}$ in a mineral wool core above the middle support are shown. A compressed area of the core extends over $800 \mathrm{~mm}$ on each side of a centreline of the support in the longitudinal $(Z)$ direction above the plane part of the top flange of the inner face. In the transverse $(X)$ direction, the stress concentrations in the core above the bend of the top flange can be observed while gradually decreasing in the negative $X$ direction toward a flange stiffener. All shown compressive stress values (up to $0.045 \mathrm{MPa}$ ) are below the adequate proportional stress limit of the mineral wool (which is $0.1 \mathrm{MPa}$; from data provided by the sandwich panel manufacturer).

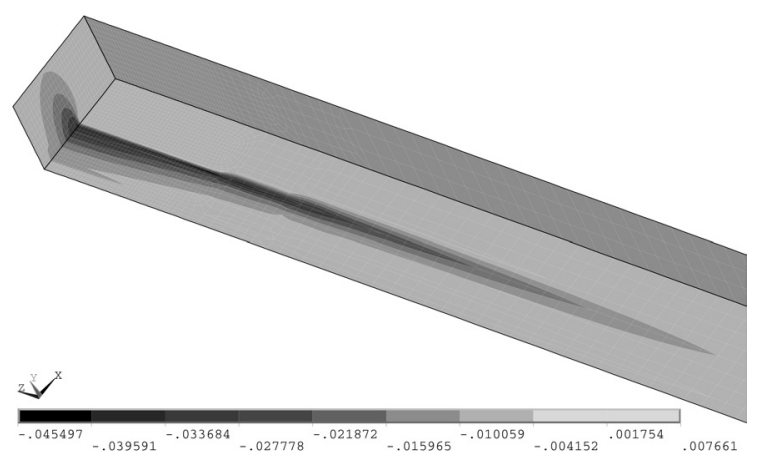

Fig. 6. Calculated normal stress $\sigma_{y}[\mathrm{MPa}]$ distribution in mineral wool core above middle support (bottom side, view from below) $(F=30 \mathrm{kN})$

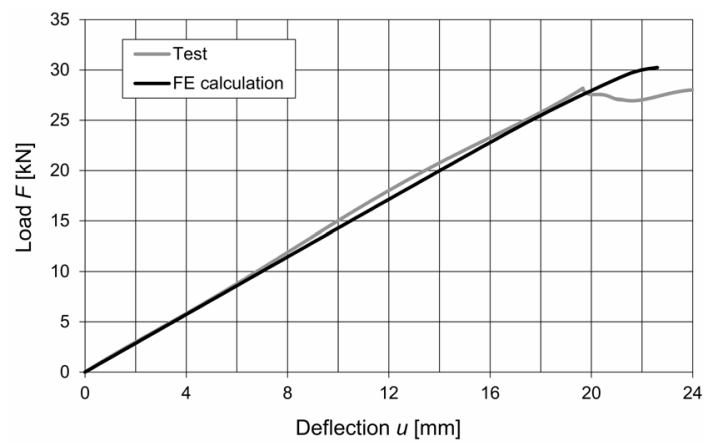

Fig. 7. Comparison of experimental and calculated relation load $F$ vs. deflection $u$ of the tested two-span roof sandwich panel

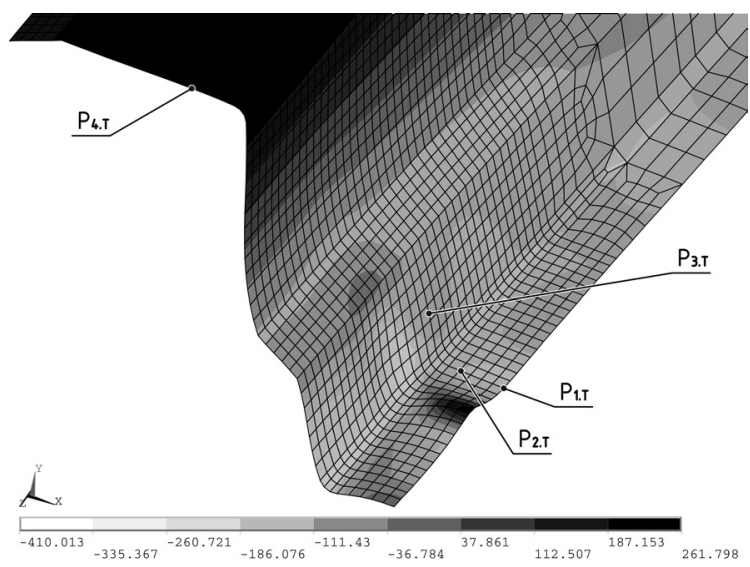

Fig. 8. Calculated axial bending stresses $\sigma_{z}[\mathrm{MPa}]$ at top surface of strongly profiled steel face above the middle support; measuring points $\mathrm{P}_{1 . T} \ldots \mathrm{P}_{4 . \mathrm{T}}$ are marked and labelled (top side, view from top) $(\mathrm{F}=30 \mathrm{kN})$

It is the characteristics of sandwich panels with strongly profiled faces at a support subject to a positive support reaction that the face distributes 


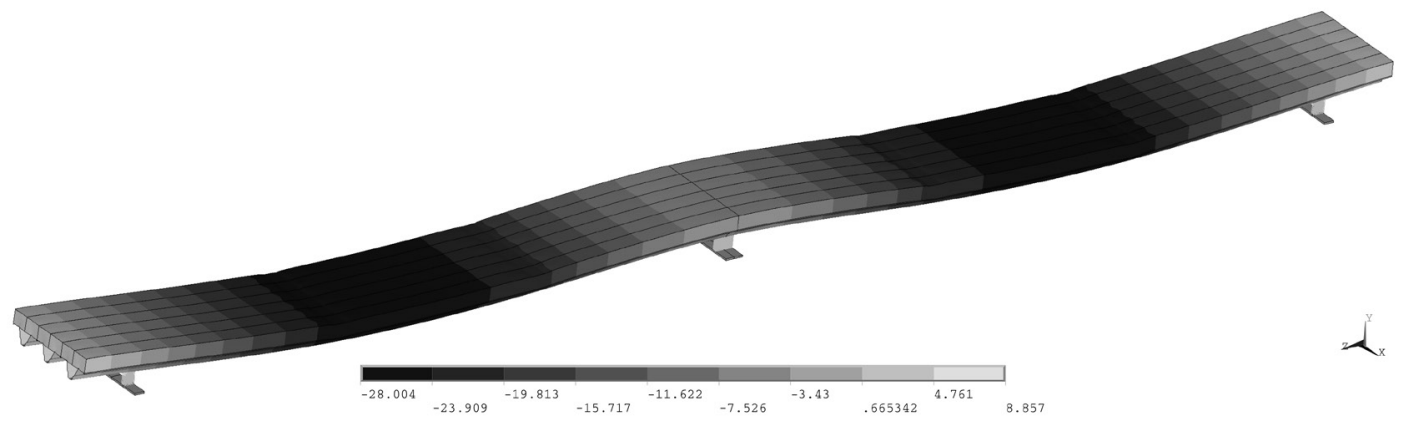

Fig. 9. Calculated deflections of the tested two-span roof sandwich panel (display created using symmetry expansion) $(F=30 \mathrm{kN})$

(because of its high bending stiffness) the support reaction over the large area. Therefore, the checks of compression strength of the core on the support are no longer required [1]. In Fig. 7, a comparison of the applied load $F$ vs. the deflection $u$ obtained from calculated and experimental results (dead load deflections, of both sandwich panel and load apparatus are included and used as zero reference points) is shown. A good agreement is observed between the results in the pre-failure range (the maximum relative difference is $5 \%$ ). The value of the ultimate load obtained from experimental results is $28.1 \mathrm{kN}$ and the value of the ultimate load based on calculated results is approximately $30 \mathrm{kN}$ (a relative difference of $7 \%$ ).

Fig. 9 shows the calculated total deflection distribution (deflections due to the dead load of sandwich panel and load apparatus included) along the investigated sandwich panel in a double span configuration at calculated ultimate load $(F=30 \mathrm{kN})$.

Fig. 8 shows the calculated distribution of axial bending stresses $\sigma_{z}[\mathrm{MPa}]$ on the top surface (view from the top) of the inner steel face above the middle support (at a calculated ultimate load $F=30 \mathrm{kN}$ ). Wrinkles in the bottom flange and in the web (near bottom flange) of the profiled face due to the compression stresses can be noticed. The measuring points $\left(\mathrm{P}_{1 . \mathrm{T}} \ldots \mathrm{P}_{4 . \mathrm{T}}\right)$ where the axial bending stresses $\sigma_{z}$ at the top surface were measured in the experiment are also marked and labelled.

In Fig. 10, the calculated and experimental axial bending stresses $\sigma_{\mathrm{z}}$ on the top surface (at measuring points $\mathrm{P}_{1 . T} \quad \ldots \quad \mathrm{P}_{4 . \mathrm{T}}$ ) and the bottom surface (at measuring points $\mathrm{P}_{1 . \mathrm{B}} \ldots \mathrm{P}_{4 . \mathrm{B}}$ ) of the inner steel face above the middle support compared to applied load $F$ are presented. The compressive axial stress values can be observed in points below the neutral axis of the face, i.e. points $\mathrm{P}_{1 . \mathrm{T}} \ldots \mathrm{P}_{3 . \mathrm{T}}$ and $\mathrm{P}_{1 . \mathrm{B}} \ldots \mathrm{P}_{3 . \mathrm{B}}$; and tensile stress values in points $\mathrm{P}_{4 . \mathrm{T}}$ and $\mathrm{P}_{4 . \mathrm{B}}$ that are above the neutral axis of the face as expected. A reasonably good agreement between the results can be noticed in the pre-buckling load range. The relative differences at a load value of $20 \mathrm{kN}$ (at $2 / 3$ value of ultimate load $F=30 \mathrm{kN}$ ) are between $28 \%$ (at points $\mathrm{P}_{2 . \mathrm{B}}$ and $\mathrm{P}_{3 . \mathrm{T}}$ ) and $33 \%$ (at point $\mathrm{P}_{4 . \mathrm{T}}$ ). However, it has to be noted that a bad quality bonding of the strain gauge at the measuring point $\mathrm{P}_{4 . T}$ was observed in the post-test inspection. But, what is more important is the thorough agreement in a size relation between the stresses on the top and bottom surfaces of the steel face at each of the four measuring locations, i.e. a positive difference between the stresses at measuring points $\mathrm{P}_{1 . \mathrm{T}}$ and $\mathrm{P}_{1 . \mathrm{B}}$, and $\mathrm{P}_{2 . \mathrm{T}}$ and $\mathrm{P}_{2 . \mathrm{B}}$, respectively, and a negative difference between the stresses at measuring points $\mathrm{P}_{3 . \mathrm{T}}$ and $\mathrm{P}_{3 . \mathrm{B}}$, and $\mathrm{P}_{4 . \mathrm{T}}$ and $\mathrm{P}_{4 . \mathrm{B}}$, respectively. The established differences in the axial bending stresses are consistent with the deformed shape of the profiled steel face at corresponding points, as shown in Fig. 8 (and consequently also in Fig. 5).

\section{CONCLUSIONS}

Numerical simulations were used to study the structural behaviour of sandwich panels with a flat outer and strongly profiled inner face used in the roof claddings. Finite element analyses of a bending test of a continuous long span sandwich panel (in double span configuration and four transverse loads) were conducted. A "support reaction capacity of the profile" failure mode was established and the ultimate transverse load of the investigated configuration was determined. The results from the numerical simulations finite elements model were successfully validated using measured deflection and stress results from the experiment. Good agreement was found between the experimental and calculated relation of applied load $F$ vs. deflection $u$ (the maximum relative difference in pre-buckling load range is $5 \%$ ) and between the experimental and calculated ultimate load (relative difference of $7 \%$ ). 

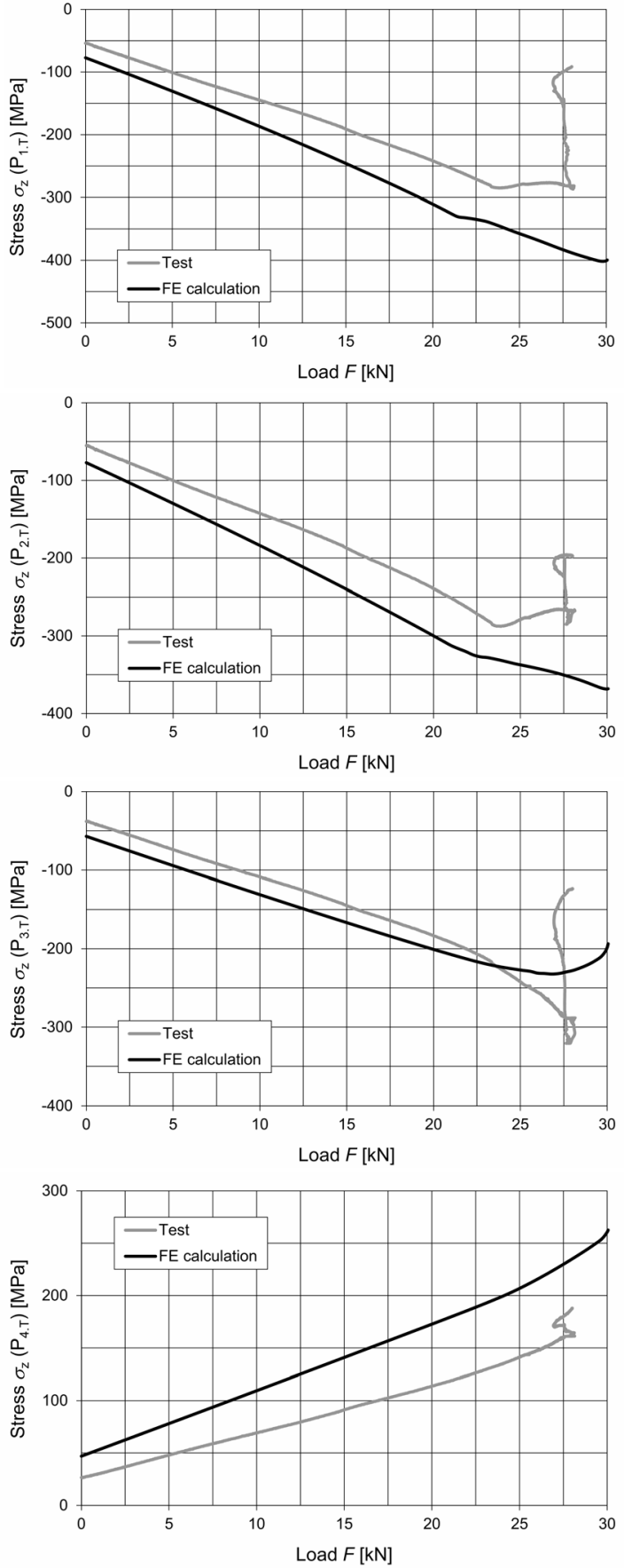
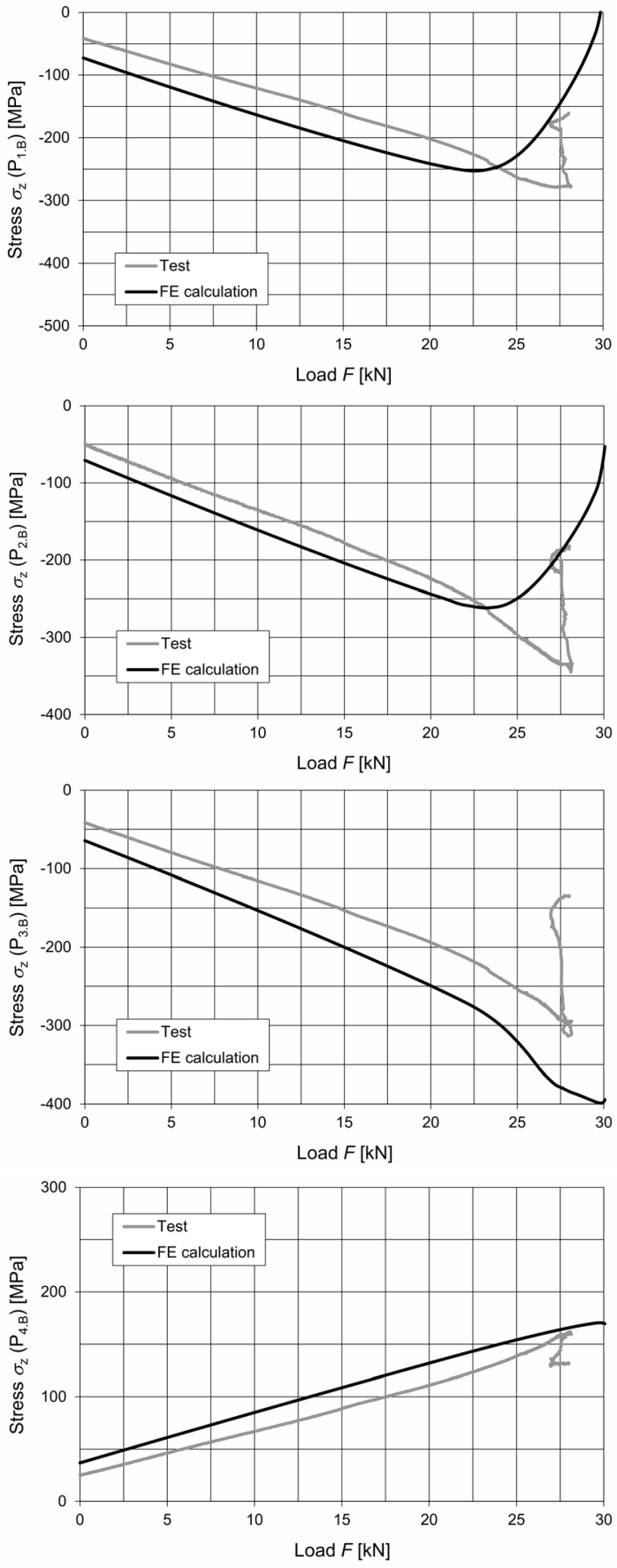

Fig. 10. Comparison of experimental and calculated axial bending stresses $\sigma_{z}[\mathrm{MPa}]$ in relation to applied load $F[\mathrm{kN}]$ at the top and the bottom surface of inner strongly profiled steel face at measurement points $\left(\mathrm{P}_{1 . \mathrm{T}} \ldots \mathrm{P}_{4 . \mathrm{T}}\right.$ and $\left.\mathrm{P}_{1 . \mathrm{B}} \ldots \mathrm{P}_{4 . \mathrm{B}}\right)$ of the tested two-span roof sandwich panel

\section{REFERENCES}

[1] Davies, J.M. (2001). Lightweight Sandwich Construction. Blackwell Science, Oxford, DOI:10.1002/9780470690253.

[2] Zenkert, D. (1997). The Handbook of Sandwich Construction. Chameleon Press, London.
[3] Hassinen, P., Martikainen, L. (1994). Analysis and Design of Continuous Sandwich Beams. 12 $2^{\text {th }}$ International Specialty Conference on Cold-Formed Steel Structures, p. 523-538.

[4] Hassinen, P., Martikainen, L. (1996). Design Models of Continuous Sandwich Panels. 13th International Specialty Conference on Cold-Formed Steel Structures, p. 293-307. 
[5] EN 14509:2013. Self-Supporting Double Skin Metal Faced Insulating Panels - Factory Made Products - Specifications. European Committee for Standardization, Brussels.

[6] Misiek, T., Hassinen, P. (2010). Unified Approach for the Local Buckling Of Sandwich Panels and Trapezoidal Sheeting. Proceedings: W056 - Special Track 18th CIB World Building Congress, Salford, p. 14-26.

[7] Hassinen, P. (1997). Evaluation of the compression strength of profiled metal sheet faces of sandwich panels. Thin-Walled Structures, vol. 27, no. 1, p. 31-41, D0l:10.1016/02638231(96)00022-5.

[8] EN 1993-1-3:2006. Eurocode 3: Design of Steel Structures - Part 1-3: General Rules - Supplementary Rules for Cold Formed Members and Sheeting. European Committee for Standardization, Brussels.

[9] EN 1993-1-5:2006. Eurocode 3: Design of Steel Structures Part 1-5: Plated Structural Elements. European Committee for Standardization, Brussels.

[10] Pokharel, N., Mahendran M. (2004). Finite element analysis and design of sandwich panels subject to local buckling effects. Thin-Walled Structures, vol. 42, no. 4., p. 589-611, DOI:10.1016/j.tws.2003.08.002.

[11] Pokharel, N., Mahendran M. (2005). An investigation of lightly profiled sandwich panels subject to local buckling and flexural wrinkling effects. Journal of Constructional Steel Research, vol. 61, no. 7, p. 984-1006, D0l:10.1016/j.jcsr.2004.12.008.

[12] Rädel, F., Lange, J. (2011). Tragfähigkeit von Sandwichelementen mit profilierten Deckschichten und
Öffnungen. Stahlbau, vol. 80, no. 9, p. 656-661, D0I:10.1002/ stab.201101469.

[13] Ilić, I., Petrovic, Z., Maksimović, M., Stupar, S., Stamenković, D. (2012). Computation method in failure analysis of mechanically fastened joints at layered composites. Strojniški vestnik - Journal of Mechanical Engineering, vol. 58, no. 9, p. 553-559, DOl:10.5545/sv-jme.2011.157.

[14] N/A (2012). Elements Reference. Release 14.5 Documentation for ANSYS. Ansys Inc., Canonsburg.

[15] Kovačević, D., Budak, I., Antić, A., Kosec, B. (2011). Special finite elements: Theoretical background and application. Tehnički vjesnik - Technical Gazette, vol. 18, no. 4, p. 649-655.

[16] Croccolo, D., De Agostinis, M., Vincenzi, N. (2011). structural analysis of an articulated urban bus chassis via FEM: a methodology applied to a case study. Strojniški Vestnik Journal of Mechanical Engineering, vol. 57, no. 11, p. 799809, D0l:10.5545/sv-jme.2011.077.

[17] Čuk, M., Štih, S., Jerman, B. (2013). Finite element analysis of sandwich panels with longitudinal joints and large openings. Tehnički vjesnik - Technical Gazette, vol. 20, no. 2, p. 275-284.

[18] Djemana M., Hrairi M. (2016). Modelling and simulation of impedance-based damage monitoring of structures. International Journal of Simulation Modelling, vol. 15, no. 3, p. 295-408, D0I:10.2507/IJSIMM15(3)1.338.

[19] Wang Y., Lu Y. J., Si C. D., Sung P. (2016). Tire-pavement coupling dynamic simulation under tire high-speed-rolling condition. International Journal of Simulation Modelling, vol. 15, no. 2, p. 236-248, D0I:10.2507/IJSIMM15(2)4.332. 